\title{
Determinants of Wage Differences Among Midsouth Chemical Companies
}

\author{
Semoon Chang and A. Douglas Stutsman*
}

\section{INTRODUCTION}

Most studies on the wage effect of unions indicate that the effect is direct and positive although actual wage differentials between union and non-union workers vary with particular settings of these studies. Ashenfelter, for instance, claims on the basis of 1961 to 1966 data for medium-sized cities that the unionization of fire fighters raised wages by six to sixteen percent and raised annual salaries by zero to ten percent above the nonunion level. [1] With 1968 BLS data on 1149 establishments in manufacturing, Bailey and Schwenk found union wages to be higher than nonunion wages by 72.1 cents. [2] Based on 1967 data of the Survey of Economic Opportunity, Boskin found wage differentials to range from zero to eighty cents per hour favoring union workers, although the difference was as large as fifteen to twenty percent for strong union occupations such as craftsmen, and was close to zero for light union occupations such as sales persons and managers. [3] The same data led Schmidt and Strauss to conclude that union membership has a positive but insignificant effect on earnings. [8] According to Hamermesh the wage effect of unions of clerical workers in manufacturing is small at five percent, but for blue collar unions the effect is larger at about twenty percent. This finding is based on the BLS annual wage surveys during the early 1960's. [4] On the basis of aggregated data for twenty-nine major industries during 1960's, Mason states that wages are typically higher in unions than in nonunion plants within the same industry, and that this relationship generally holds true even under regional examination. [6] Throop's conclusion that wage differentials are 12.9 percent and five percent depending upon whether or not the effect of nonunion labor supply is considered is based on 1950 and 1960 BLS data on estimates of union contract coverage. [9] An informative study by Weiss, based on 1959 data, concludes that high wages and incomes in concentrated industries result from unionization rather than industry concentration. Thus Weiss states "it is unionism or the threat of unionism that produces high wages in concentrated industries." [10, p. 115] Finally, upon review of about twenty studies, Lewis concludes that the average wage effect of unionism in comparison with nonunion labor was 25 percent in 1931-33, 10 to 20 percent by the beginning of World War II,

*Both are Associate Professors of Economics, University of South Alabama, Mobile, Alabama. We deeply appreciate suggestions and corrections made by anonymous referees of this review. 
zero to five percent during 1945-1949, and about 10 to 15 percent in 1957-58. [5].

The main objective of our study is to assess the impact of unions in an industry consisting of both union and nonunion firms. We examine the impact of unions on wages paid by producers of industrial chemicals in the Midsouth region.

The industry characteristics and the data collected for our study appear very well suited to this purpose. We are concerned with the Midsouth Chemical Group, an organization comprised of thirty-six chemical companies in Alabama, Florida, Georgia, Mississippi, and parts of Tennessee and Louisiana. Ninety percent of these companies are independently owned. The group meets once a quarter, updating each other as to what is happening to their individual establishments with regard to employee wages and fringe benefits such as late shift premium, number of holidays, and meal allowances. Of the thirty-six companies, hourly employees of seventeen companies are all unionized, those of another seventeen companies are totally nonunionized, those of one company are almost totally unionized, and those of the remaining one company are partially unionized. The partially unionized company is treated as two companies in our study since the company maintains separate wage scales for unionized and nonunionized workers. This study is based on the cross-section wage data of the Group which were collected in June, 1977, and which are summarized in the Appendix.

\section{A MODEL OF INTER-FIRM WAGE DIFFERENCES}

\section{The Model}

We postulate the following model in which inter-firm differences in hourly wages for identical types of work are assumed to depend upon a set of independent variables:

$$
\text { (1) } \Delta W_{i}=a_{i}+\sum_{j=1}^{9} b_{i j} X_{j}+e_{i}
$$

where types of work (i) to be estimated by the model include:

1. $\mathrm{LTR}=$ laborer top rate

2. $\mathrm{LSR}=$ laborer start rate

3. $\mathrm{JM}=$ journeyman mechanic

4. $\mathrm{MHTR}=$ mechanic helper top rate

5. MHSR = mechanic helper start rate

6. $\mathrm{JE}=$ journeyman electrician

7. JIM = journeyman instrument mechanic

8. $\mathrm{CO}=$ chief operator

9. $\mathrm{FCO}=$ first class operator

10. OHTR $=$ operator helper top rate

11. OHSR = operator helper start rate

12. $\mathrm{LTTR}=$ lab technician top rate

13. $\mathrm{LTSR}=$ lab technician start rate

14. AST $=$ average straight time hourly wage 
And the independent variables for each of these equations $\left(\mathrm{X}_{\mathbf{j}}\right)$ are tentatively identified as:

1. EMP $=$ number of hourly employees, measuring the size of a firm

2. UNION = dummy variable indicating a union status; 1 for labor union and 0 for no union

3. LSP = late shift premium; an average of the second and the third shift premiums in dollar

4. $\mathrm{HOL}=$ number of holidays during a year

5. $\mathrm{MA}=$ meal allowances in dollar

6. $\mathrm{LWI}=$ dummy variable indicating the date of latest wage increases; 1 for latest wage increases within six months prior to the date of data collection and 0 for latest wage increases beyond the past six months

7. $\mathrm{PROD}=$ average labor productivity

8. $\mathrm{CPI}=$ cost of living index

9. $\mathrm{MGT}=$ management factor

Data for PROD, CPI, and MGT, the last three independent variables of equation (1), are either unavailable or simply unobservable. We drop these variables by assuming that the productivity, cost of living, and the managerial efficiency are the same for all thirty-six companies included in the Group. The assumption seems quite acceptable since there exists a high degree of homogeneity in technology in the southeastern chemical industry, all these firms are located in the same southeastern part of the country, and since the managerial ability, although difficult to measure in the absence of profit and other data for individual firms, may also be very much alike as evidenced by frank and frequent exchange of confidential data on wages and fringe benefits. We finally add $\bar{W}$ to both sides of equation (1), thus obtaining:

$$
W_{i}=\left(a_{i}+W_{i}\right)+\sum_{j=1}^{6} b_{i j} X_{j}+e_{i}
$$

Equation (2) is our basic model which is actually estimated. Equations (1) and (2), and a possible third alternative specification in which both dependent and independent variables are measured in deviations from their means, will all give us identical statistical results, with the exception of the values of the constant term which are $a_{i}, a_{i}+\bar{W}_{i}$, and zero, respectively for equation (1), equation (2), and the third alternative. One advantage of equation (2) over the two alternatives is that it reveals more clearly the impact of dropping the productivity variable. To be specific, we expect $R^{2} s$ to be quite low for all fourteen equations, since a large portion of absolute levels of wages, we believe, is based on the level of workers' productivities.

Estimates of equation (2) are summarized in Table 1. The first column in Table 1 refers to the number of observations for corresponding equations. Wage data were not supplied by selected companies for some of these job classifications. Two different figures are presented for the constant term 
for each of fourteen equations. The upper ones $\left(\hat{a}_{i}+\bar{W}_{i}\right)$ are obtained from equation (2) in which dependent variables are the actual wages (W), while the lower ones $\left(\hat{a}_{i}\right)$ are obtained from equation (1) where deviations $\left(\Delta \mathrm{W}_{\mathrm{i}}\right)$ are used as dependent variables. Figures in the parentheses are t-values.

\section{Wage Impact of Unionization}

Our primary interest relates to the UNION variable. There are five estimated coefficients of the union variable which are statistically significant at, at least, a ten percent level against a two-tail test, and all five have negative signs. These include journeyman mechanic, journeyman electrician, first class operator, lab technician top rate, and average straight-time hourly wages. Of the remaining categories, only four have positive signs, and all four are statistically insignificant. Thus our study indicates that, among the thirty-six firms, wage differentials for each job category are quite small. Further, wages in union companies are no higher than in nonunion companies. In fact, in five of the fourteen job categories, the only five having statistical significance, nonunion wages are somewhat higher than union wages. The differential favoring nonunion wages is about forty cents per hour.

Those results are subject to at least two interpretations.

1. The unions have had little or no impact on market-determined wages except to induce some firms to pay wages somewhat above the competitive level in order to discourage unionization. The small wage differentials among firms indicate that all are hiring in the same competitive labor market.

2. Unions have raised wages above levels which would exist in the absence of union intervention into the labor market. Nonunion firms are paying the higher wages, and in some cases a premium, in order to discourage unionization.

We are inclined toward the second interpretation, primarily because the wage levels appear relatively high for the midsouth region. It is difficult to make meaningful inter-industry comparisons between jobs and rates of pay where job characteristics are different in different industries. But this difficulty is hardly present in the case of unskilled, common labor. It is common knowledge within the region that common labor can be hired at the minimum wage, and for less where the law, or lack of its enforcement, allows. For example, unskilled labor used in nonunion residential construction and farm labor can be employed at the minimum wage. There is no reason to expect a higher market wage in the case of the chemical companies. The work is typical of unskilled labor, eg., loading and unloading vehicles, moving materials about the plant, etc. It is not particularly difficult or hazardous. Further, the position of laborer in one of these firms offers the advantage of steady work. It is not subject to seasonal layoffs or layoffs due to weather conditions. In the absence of union influence it should be quite easy to fill these positions satisfactorily by offering the minimum wage. The wage paid unskilled labor by these firms is almost twice the minimum wage. 
The interpretation that unions have had an impact on wages is supported by the strong evidence indicating that nonunion firms are attempting to discourage unionization. If, after unionizing half the firms in the region, the unions had not succeeded in raising wages, it is questionable that there would be much effort to stop their further expansion. Yet, there appears to be a very definite strategy among all thirty-six firms, union and nonunion alike, to limit the spread of the unions. The thirty-six firms meet quarterly and exchange very elaborate and detailed information concerning wages and fringe benefits. This information, in addition to being useful to union firms in the collective bargaining process, enables nonunion firms to avoid guesswork in establishing wage levels designed to discourage unionization. The one firm under our survey in which hourly workers are partially unionized listed two different wages for all job classifications; one for union workers and the higher one for nonunion workers.

It is interesting to speculate on the reasoning underlying this strategy. Is the strategy in the interest of all the companies, union and nonunion alike? Recall that approximately half of the firms are nonunion. If union wages are higher than prevailing market wages, why do the nonunion firms not pay the lower market wages and sell their products at prices below these of union firms? In this manner they should eventually drive the union firms-and the unions-out of the market. Or why do they not pay the lower market wages and sell their products at approximately the prices charged by the higher-cost union firms? In this manner they would enjoy continuing profits while avoiding a fight for survival. They must fear that paying the lower wages would invite attempts by their employees to form unions and that the attempts would succeed. Why do the union firms provide detailed information which helps their nonunion competitors in their fight to prevent unionization? Are they not helping their rivals to maintain a competitive advantage? Or, do they feel assured that their nonunion rivals will continue to pay the higher wages even though not compelled to do so?

Since all firms are willingly engaged in this procedure, and since approximately half are union and half nonunion, it would seem logical that both groups believe the strategy is in their interests. Nonunion firms are paying the union wages, and sometimes more, in order to prevent unionization of their plants, and they are being assisted in doing so by their rivals who have been unionized. Thus all firms, union and nonunion alike, must believe it desirable and important to prevent unions from moving into nonunion firms. Why? They probably believe that if all, or almost all, of the firms became unionized, the bargaining power of the unions would be increased substantially and that as a result wage costs would become noticeably higher. They are almost certainly correct in this belief. If the unions can eliminate the threat of nonunion competition, they greatly reduce the elasticity of demand for the labor they are selling. When the entire industry is unionized, unions are assured that wage-induced price increases will be market-wide. They are no longer restrained by the threat of competition in the product market from low-cost nonunion firms. Thus, even 
though the intra-industry product market may be very competitive, unions can base their wage demands on market demand for the product rather than on the much more elastic demand facing individual firms. This situation is exemplified by the building trades unions in most of the country.

The present strategy is clearly in the interest of the union firms. Stopping the spread of unions limits the bargaining power of the unions, thus holding down the wage costs of these firms. In addition, the strategy requires that nonunion firms sacrifice whatever wage-cost advantage they have over their unionized rivals.

The strategy is probably in the interest of the nonunion firms as well, but this is not certain. In fact, the present strategy probably would not continue except for a key element of uncertainty. That uncertainty concerns the outcome if nonunion firms attempted to pay wages substantially below union wages. One possible outcome is that the employees of nonunion firms would attempt to unionize and would be successful. The resulting increase in bargaining strength of unions would mean higher wage costs for all firms. It is this possibility that restrains the nonunion employers and prevents their taking advantage of their nonunion status, i.e., it is this possibility that induces their cooperation in the present strategy. The other possible outcome is that the nonunion employees would not succeed in forming unions and that the nonunion firms with their cost advantage would increase their market share at the expense of their union rivals. This outcome would be damaging to the unions as well as the unionized firms.

If the outcome were not uncertain, the present strategy would not continue. If it were known that employees would successfully unionize firms which paid wages lower than union wages, the unions would not face competition from low-cost nonunion labor. They would press for higher wages with the same confidence and bargaining power that would exist if the entire industry were unionized, because they would have no fear of pricing themselves out of this labor market. If it were known that employees of nonunion firms would not succeed in unionizing these firms, the nonunion firms would pay the lower wages and reap the rewards of their cost advantage. But the outcome is uncertain, and in view of this uncertainty, the strategy is rational from the standpoint of both union and nonunion firms.

\section{FURTHER ANALYSIS OF ESTIMATES}

The number of holidays and the meal allowances do not have any direct bearing on the inter-firm wage differences. Estimated coefficients are all insignificant except those of meal allowances upon chief operators and average straight time. These are statistically significant at a ten percent level. The coefficients for the dummy variable for latest wage increases all turned out positive and are statistically significant in most cases at a ten percent level. An analysis of partial coefficients of determination indicates that about forty percent of inter-firm wage differentials is explained by this variable. Wages at firms where increases were made within the previous six months from the date of data collection are consistently higher for 
all fourteen job classifications than those which were raised more than six months prior to the date of data collection. The differences range from a low thirteen cents for mechanic helper top rate (MHTR) to about ninetytwo cents for lab technician start rate (LTSR). This indicates that a significant part of apparent wage differentials is simply time lag and thus not differentials at all, and it also is evidence of the close communication among unions and among firms concerning wage matters. The size of a firm measured in the number of hourly employees and the late shift premium have a positive relationship to wage differences. This implies that wages are higher the larger the size of a firm, and that late shift premiums complement rather than compensate wage differences. These interpretations are at best tentative, however, because most estimated coefficients are statistically insignificant and because wage differences that may have been caused by these variables are extremely small.

Although, inter-firm wage differences for identical work are quite small, our model explains most of these differences. Despite low $\mathrm{R}^{2} \mathrm{~S}$ caused by the assumption of equal labor productivities among different firms, lower-half figures for each of the constant terms presented in Table 1 are close to zero, implying that little wage differences remain to be explained.

\section{CONCLUSIONS}

The major conclusions of our study are as follows. First, wages of nonunion firms are slightly higher than union firms in the Midsouth chemical industry. The threat of spreading unionization as well as actual unionization has resulted in higher wages of workers in this industry. The wage differential favoring nonunion workers ranges from zero to about forty cents per hour. Second, about forty percent of inter-firm wage differences of the Midsouth chemical industry is explained by time lags in wage increases. Third, the number of holidays, meal allowances, size of firm measured in employment, and late shift premiums do not have any direct effect upon explaining wage differences.

\section{REFERENCES}

1. Orley C. Ashenfelter, "The Effect of Unionization on Wages in the Public Sector: The Case of Fire Fighters," Industrial and Labor Relations Review 24 (January, 1971), pp. 191-202.

2. William R. Bailey, and Albert E. Schwenk, "Wage Differences Among Manufacturing Establishments," Monthly Labor Review 94 (May, 1971), pp. 16-19.

3. Michael J. Boskin, "Unions and Relative Real Wages," American Economic Review 62 (June, 1972), pp. 466-472.

4. Daniel S. Hamermesh, "White-Collar Unions, Blue-Collar Unions, and Wages in Manufacturing," Industrial and Labor Relations Review 24 (January, 1971), pp. 159-170.

5. H. Gregg Lewis, Unionism and Relative Wages in the
United States, Chicago: University of Chicago Press, 1963.

6. Sandra L. Mason, "Comparing Union and Nonunion Wages in Manufacturing," Monthly Labor Review 94 (May, 1971), pp. 20-26.

7. R. Perlman (ed.), Wage Determination: Market or Power Forces?, Boston: D. C. Heath and Co., 1964.

8. Peter Schmidt, and Robert P. Strauss, "The Effect of Unions and Earnings and Earnings on Unions: A Mixed Logit Approach," International Economic Review 17 (February, 1976), pp. 204-212.

9. Adrian W. Throop, "The Union-Nonunion Wage Differential and Cost Push Inflation," American Economic Review 58 (March, 1968), pp. 79-99.

10. Leonard W. Weiss, "Concentration and Labor Earnings," American Economic Review 56 (March, 1966), pp. 96-117. 
TABLE

ESTIMATES OF THE WAGE DIFFERENCE MODEL

\begin{tabular}{|c|c|c|c|c|c|c|c|c|c|c|}
\hline $\mathrm{n}$ & $\begin{array}{l}\text { Type of } \\
\text { Work }\end{array}$ & Constant & EMP & UNION & LSP & HOL & MA & LWI & $\mathrm{R}^{2}$ & D-W \\
\hline 29 & LTR & $\begin{array}{r}4.4440 \\
-0.3481\end{array}$ & $\begin{array}{c}0.0000 \\
(0.0934)\end{array}$ & $\begin{array}{c}0.2054 \\
(0.9427)\end{array}$ & $\begin{array}{l}-0.0028 \\
(0.6003)\end{array}$ & $\begin{array}{c}0.0398 \\
(0.6664)\end{array}$ & $\begin{array}{l}-0.1686 \\
(0.6112)\end{array}$ & $\begin{array}{c}0.4028 \\
(1.7840)\end{array}$ & 0.2125 & 2.2241 \\
\hline 29 & LSR & $\begin{array}{r}4.3377 \\
-0.1126\end{array}$ & $\begin{array}{l}-0.0004 \\
(0.6163)\end{array}$ & $\begin{array}{c}0.1427 \\
(0.4927)\end{array}$ & $\begin{array}{c}0.0018 \\
(0.2844)\end{array}$ & $\begin{array}{c}0.0217 \\
(0.2737)\end{array}$ & $\begin{array}{l}-0.1545 \\
(0.4215)\end{array}$ & $\begin{array}{c}0.5564 \\
(1.8544)\end{array}$ & 0.1591 & 2.4261 \\
\hline 35 & $\mathrm{JM}$ & $\begin{array}{r}6.2549 \\
-0.3379\end{array}$ & $\begin{array}{c}0.0008 \\
(2.0957)\end{array}$ & $\begin{array}{l}-0.3587 \\
(2.0509)\end{array}$ & $\begin{array}{c}1.5363 \\
(1.3553)\end{array}$ & $\begin{array}{c}0.0147 \\
(0.2735)\end{array}$ & $\begin{array}{l}-0.1416 \\
(0.5993)\end{array}$ & $\begin{array}{c}0.3147 \\
(1.7579)\end{array}$ & 0.3441 & 1.5017 \\
\hline 28 & MHTR & $\begin{array}{r}4.2784 \\
-1.4136\end{array}$ & $\begin{array}{c}0.0008 \\
(1.5079)\end{array}$ & $\begin{array}{l}-0.0451 \\
(0.1797)\end{array}$ & $\begin{array}{c}2.1642 \\
(1.0945)\end{array}$ & $\begin{array}{l}-0.0040 \\
(0.0573)\end{array}$ & $\begin{array}{c}0.3676 \\
(1.1296)\end{array}$ & $\begin{array}{c}0.1338 \\
(0.5237)\end{array}$ & 0.2039 & 1.9879 \\
\hline 28 & MHSR & $\begin{array}{r}4.6216 \\
-0.4784\end{array}$ & $\begin{array}{c}0.0004 \\
(0.7302)\end{array}$ & $\begin{array}{c}0.0355 \\
(0.1266)\end{array}$ & $\begin{array}{c}2.3583 \\
(1.0667)\end{array}$ & $\begin{array}{c}-0.0384 \\
(0.4993)\end{array}$ & $\begin{array}{l}-0.0249 \\
(0.0685)\end{array}$ & $\begin{array}{c}0.6295 \\
(2.2040)\end{array}$ & 0.2608 & 1.7220 \\
\hline 35 & $\mathrm{JE}$ & $\begin{array}{r}6.4666 \\
-0.2047\end{array}$ & $\begin{array}{c}0.0005 \\
(1.3338)\end{array}$ & $\begin{array}{l}-0.3966 \\
(2.0925)\end{array}$ & $\begin{array}{c}1.4903 \\
(1.2131)\end{array}$ & $\begin{array}{c}0.0377 \\
(0.6496)\end{array}$ & $\begin{array}{l}-0.3051 \\
(1.1914)\end{array}$ & $\begin{array}{c}0.4857 \\
(2.5041)\end{array}$ & 0.3737 & 1.5563 \\
\hline 35 & JIM & $\begin{array}{r}6.4021 \\
-0.3690\end{array}$ & $\begin{array}{c}0.0003 \\
(0.7974)\end{array}$ & $\begin{array}{l}-0.2125 \\
(1.3234)\end{array}$ & $\begin{array}{c}0.1006 \\
(0.0967)\end{array}$ & $\begin{array}{c}0.0751 \\
(1.5272)\end{array}$ & $\begin{array}{l}-0.2450 \\
(1.1295)\end{array}$ & $\begin{array}{c}0.3763 \\
(2.2902)\end{array}$ & 0.3180 & 1.2944 \\
\hline 24 & $\mathrm{CO}$ & $\begin{array}{l}7.8077 \\
1.3287\end{array}$ & $\begin{array}{l}-0.0001 \\
(0.1597)\end{array}$ & $\begin{array}{c}-0.3338 \\
(1.2970)\end{array}$ & $\begin{array}{c}3.1231 \\
(1.8251)\end{array}$ & $\begin{array}{c}-0.0668 \\
(0.2237)\end{array}$ & $\begin{array}{l}-0.6429 \\
(1.9283)\end{array}$ & $\begin{array}{c}0.5507 \\
(1.7538)\end{array}$ & 0.4244 & 1.5605 \\
\hline 35 & $\mathrm{FCO}$ & $\begin{array}{r}5.9385 \\
-0.3525\end{array}$ & $\begin{array}{c}0.0001 \\
(0.2578)\end{array}$ & $\begin{array}{l}-0.4393 \\
(2.0876)\end{array}$ & $\begin{array}{c}1.6679 \\
(1.2231)\end{array}$ & $\begin{array}{c}0.0273 \\
(0.4241)\end{array}$ & $\begin{array}{l}-0.1071 \\
(0.3766)\end{array}$ & $\begin{array}{c}0.3868 \\
(1.7962)\end{array}$ & 0.2680 & 1.3364 \\
\hline 30 & OHTR & $\begin{array}{r}5.2137 \\
-0.4016\end{array}$ & $\begin{array}{c}0.0005 \\
(1.0661)\end{array}$ & $\begin{array}{l}-0.2761 \\
(1.1408)\end{array}$ & $\begin{array}{c}1.8415 \\
(1.2221)\end{array}$ & $\begin{array}{l}-0.0288 \\
(0.4069)\end{array}$ & $\begin{array}{c}0.0420 \\
(0.1163)\end{array}$ & $\begin{array}{c}0.4544 \\
(1.9127)\end{array}$ & 0.2351 & 1.8838 \\
\hline 30 & OHSR & $\begin{array}{r}4.3910 \\
-0.7495\end{array}$ & $\begin{array}{c}0.0004 \\
(0.7678)\end{array}$ & $\begin{array}{l}-0.0540 \\
(0.1921)\end{array}$ & $\begin{array}{c}3.3485 \\
(1.9158)\end{array}$ & $\begin{array}{c}-0.0604 \\
(0.7367)\end{array}$ & $\begin{array}{c}0.0813 \\
(0.1944)\end{array}$ & $\begin{array}{c}0.7689 \\
(2.7905)\end{array}$ & 0.3327 & 2.1913 \\
\hline 26 & LTTR & $\begin{array}{r}3.9489 \\
-2.5671\end{array}$ & $\begin{array}{c}0.0012 \\
(1.6335)\end{array}$ & $\begin{array}{l}-1.1499 \\
(3.3521)\end{array}$ & $\begin{array}{c}1.6981 \\
(0.6263)\end{array}$ & $\begin{array}{c}0.0940 \\
(0.2075)\end{array}$ & $\begin{array}{c}0.6561 \\
(1.0611)\end{array}$ & $\begin{array}{c}0.4758 \\
(1.3936)\end{array}$ & 0.4674 & 1.4624 \\
\hline 26 & LTSR & $\begin{array}{l}-1.9785 \\
-6.9184\end{array}$ & $\begin{array}{c}0.0002 \\
(0.2618)\end{array}$ & $\begin{array}{c}0.0096 \\
(0.0312)\end{array}$ & $\begin{array}{c}3.2931 \\
(1.3502)\end{array}$ & $\begin{array}{c}0.4913 \\
(1.2058)\end{array}$ & $\begin{array}{c}0.4839 \\
(0.8700)\end{array}$ & $\begin{array}{c}0.9245 \\
(3.0103)\end{array}$ & 0.4151 & 2.3437 \\
\hline 35 & AST & $\begin{array}{l}6.1264 \\
0.1034\end{array}$ & $\begin{array}{l}-0.0001 \\
(0.1517)\end{array}$ & $\begin{array}{l}-0.3779 \\
(1.7275)\end{array}$ & $\begin{array}{c}3.1026 \\
(2.1882)\end{array}$ & $\begin{array}{c}0.0263 \\
(0.3928)\end{array}$ & $\begin{array}{l}-0.5220 \\
(1.7659)\end{array}$ & $\begin{array}{c}0.6005 \\
(2.6821)\end{array}$ & 0.3904 & 2.2488 \\
\hline
\end{tabular}


APPENDIX

Summary of Data on Wages and Fringe Benefits of Midsouth Chemical Companies

\begin{tabular}{|c|c|c|c|c|c|c|c|c|c|c|c|}
\hline No. & $\begin{array}{c}1 \\
\text { EMP }\end{array}$ & $\begin{array}{c}2 \\
\text { UNION }\end{array}$ & $\begin{array}{c}3 \\
\text { LTR }\end{array}$ & $\begin{array}{c}4 \\
\text { LSR }\end{array}$ & $\begin{array}{c}5 \\
\mathrm{JM}\end{array}$ & $\begin{array}{c}6 \\
\text { MHTR }\end{array}$ & $\begin{array}{c}7 \\
\text { MHSR }\end{array}$ & $\begin{array}{c}8 \\
\mathrm{JE}\end{array}$ & $\begin{array}{c}9 \\
\text { JIM }\end{array}$ & $\begin{array}{c}10 \\
\mathrm{CO}\end{array}$ & $\begin{array}{c}11 \\
\text { FCO }\end{array}$ \\
\hline 1 & 249 & 0 & \multicolumn{2}{|c|}{ CONTRACT } & 6.98 & 6.32 & 4.44 & 6.98 & 6.98 & 6.98 & 6.32 \\
\hline 2 & 106 & 106 & 5.31 & 5.31 & 7.04 & 6.29 & 5.98 & 7.04 & 7.04 & 7.04 & 6.57 \\
\hline 3 & 339 & 0 & 4.41 & 3.90 & 6.96 & 4.69 & 4.41 & 6.96 & 6.96 & - & 6.96 \\
\hline 4 & 418 & 0 & - & - & 7.07 & 5.01 & 4.24 & 7.07 & 7.07 & - & 7.07 \\
\hline 5 & 919 & 919 & 5.04 & 4.92 & 6.75 & 5.94 & 5.94 & 7.09 & 7.19 & 6.74 & 6.25 \\
\hline 6 & 0 & 0 & \multicolumn{2}{|c|}{ CONTRACT } & 7.05 & - & - & 7.05 & 7.05 & 6.72 & 5.76 \\
\hline 7 & 708 & 708 & 4.05 & 3.00 & 6.70 & 6.61 & 4.00 & 6.70 & 6.70 & 5.75 & 5.20 \\
\hline 8 & 110 & 0 & 4.92 & 4.82 & 6.73 & 5.56 & 5.46 & 7.02 & 7.02 & 6.73 & 6.18 \\
\hline 9 & 150 & 0 & - & 4.35 & 6.58 & 5.65 & 4.52 & 6.58 & 6.58 & 6.58 & 6.12 \\
\hline 10 & 145 & 134 & 4.04 & 3.79 & 4.90 & 4,29 & 4.04 & 4.90 & - & 4.89 & 4.74 \\
\hline 11 & 41 & 0 & - & - & - & - & - & 7.38 & 7.38 & 7.16 & 6.72 \\
\hline 12 & 150 & 0 & 5.41 & 5.29 & 7.17 & 5.78 & 5.66 & 7.17 & 7.17 & 7.17 & 6.69 \\
\hline 13 & 105 & 102 & 4.42 & 4.42 & 6.20 & 5.35 & 5.25 & 6.20 & 6.20 & - & $\begin{array}{l}5.60 \\
5.29\end{array}$ \\
\hline 14 & 730 & 650 & 4.28 & 4.28 & 6.46 & 4.82 & 4.36 & 5.92 & 6.05 & 5.60 & 5.98 \\
\hline 15 & 151 & 151 & - & 2.99 & 6.35 & 5.98 & 4.96 & 6.35 & 6.35 & 6.35 & 5.75 \\
\hline 16 & 78 & 78 & 4.54 & 4.45 & 6.17 & 5.45 & 5.36 & 6.17 & 6.17 & - & 6.57 \\
\hline 17 & 156 & 0 & 4.58 & 4.00 & 6.57 & 6.08 & 5.45 & 6.57 & 6.57 & - & \\
\hline 18 & 15 & 15 & 4.62 & 4.62 & 5.78 & 5.35 & 4.80 & 5.78 & 5.78 & 5.78 & - \\
\hline \multirow[t]{2}{*}{19} & \multirow[t]{2}{*}{214} & $\underline{130}$ & - & - & $\underline{5.65}$ & $\underline{5.20}$ & $\underline{4.70}$ & $\underline{5.65}$ & $\underline{5.65}$ & - & $\underline{5.43}$ \\
\hline & & $\frac{74}{84}$ & - & - & 6.23 & 5.70 & $\overline{5.06}$ & 6.23 & $\overline{6.23}$ & - & 6.08 \\
\hline 20 & 752 & 0 & 4.56 & 4.46 & 6.61 & 5.51 & 5.51 & 6.66 & 6.66 & 6.48 & 6.23 \\
\hline 21 & 192 & 188 & 5.73 & 5.66 & 6.52 & - & - & 6.52 & 6.52 & 6.52 & 6.29 \\
\hline 22 & 363 & 0 & 4.37 & 4.27 & 6.61 & - & - & 6.61 & 6.61 & 6.37 & 5.87 \\
\hline 23 & 504 & 0 & 4.48 & 3.81 & 6.94 & 6.72 & 5.71 & 6.94 & 6.94 & 6.94 & 6.72 \\
\hline 24 & 0 & 0 & - & - & 7.50 & 6.53 & 5.18 & 7.50 & 7.50 & - & 7.36 \\
\hline 25 & 364 & 0 & - & - & 6.50 & 5.85 & 5.20 & 6.50 & 6.50 & 6.50 & 6.50 \\
\hline 26 & 546 & 546 & 6.12 & 5.94 & 7.93 & 6.93 & 6.83 & 7.93 & 7.93 & 8.11 & 7.84 \\
\hline 27 & 214 & 214 & 5.29 & 4.53 & 7.30 & - & - & 7.54 & 7.54 & - & 6.85 \\
\hline 28 & 685 & 685 & 6.07 & 4.81 & 7.22 & 6.54 & 6.39 & 7.35 & 7.35 & - & 7.18 \\
\hline 29 & 147 & 147 & 4.52 & 4.42 & 6.82 & 5.27 & 5.17 & 7.07 & 7.07 & - & 6.68 \\
\hline 30 & 198 & - & - & 5.24 & 6.99 & 5.67 & 5.67 & 7.43 & 7.43 & - & 6.98 \\
\hline 31 & 466 & 454 & 4.41 & 4.19 & 6.32 & 6.01 & 4.34 & 6.32 & 6.32 & 5.90 & 5.67 \\
\hline 32 & 86 & 86 & 4.63 & 4.63 & 5.61 & - & - & 5.72 & - & 5.72 & 5.61 \\
\hline 33 & 190 & 190 & 4.57 & 4.44 & 6.55 & - & - & - & 6.87 & 6.95 & 6.45 \\
\hline 34 & 188 & 0 & 4.14 & 3.28 & 6.57 & 5.46 & 4.26 & 6.57 & 6.57 & 7.05 & 6.57 \\
\hline 35 & 63 & 0 & 5.31 & 5.03 & 7.11 & - & - & 7.27 & 7.27 & - & 6.80 \\
\hline 36 & 200 & 200 & 4.82 & 4.70 & 6.27 & 5.34 & 5.10 & CONT & AC:T & 6.41 & 6.15 \\
\hline
\end{tabular}

NOTES: 1. All symbols are defined in the paper except SSP and TSP which stand respectively for second shift and third shift premiums.

2. Dashed lines represent information either unavailable or unclear.

3. In firm No. 19, 130 of 214 hourly employees are unionized and the remaining 84 are not. 


\section{APPENDIX}

Summary of Data on Wages and Fringe Benefits of Midsouth Chemical Companies

\begin{tabular}{|c|c|c|c|c|c|c|c|c|c|}
\hline 12 & 13 & 14 & 15 & 16 & $\begin{array}{c}17 \\
\text { SSP }\end{array}$ & $\begin{array}{c}18 \\
\text { TSP }\end{array}$ & $\begin{array}{c}19 \\
\mathrm{HOL}\end{array}$ & $\begin{array}{c}20 \\
\text { AST }\end{array}$ & 21 \\
\hline OHTR & OHSR & LTTR & LTSR & & & & & & \\
\hline 5.91 & 4.44 & 6.92 & 4.38 & $8 / 1 / 76$ & .16 & .25 & 10 & 5.98 & 2.00 \\
\hline 6.15 & 5.65 & - & - & $6 / 1 / 77$ & .16 & .32 & 11 & 6.03 & 3.00 \\
\hline 5.83 & 4.96 & 6.40 & 4.50 & $6 / 21 / 76$ & .16 & .25 & 10 & 6.20 & 1.50 \\
\hline- & - & 6.89 & 5.78 & $12 / 5 / 76$ & .20 & .40 & 10 & 6.74 & - \\
\hline 5.94 & 5.94 & 6.45 & 5.41 & $1 / 16 / 77$ & .15 & .25 & 11 & 6.50 & 1.25 \\
\hline- & 4.73 & 6.72 & 4.73 & $7 / 19 / 76$ & .29 & .29 & 10 & 5.87 & 1.75 \\
\hline 4.60 & 3.20 & 4.87 & - & $10 / 27 / 76$ & .14 & .14 & 10 & 4.72 & - \\
\hline 5.56 & 5.46 & 6.30 & 6.20 & $1 / 1 / 77$ & .15 & .30 & 10 & 6.26 & 2.00 \\
\hline 5.65 & 4.52 & 5.65 & 4.52 & $8 / 1 / 76$ & \multicolumn{2}{|c|}{ \$60/Month } & 10 & 6.35 & 2.00 \\
\hline 4.29 & 4.13 & 5.25 & 3.52 & $12 / 8 / 76$ & .10 & .15 & 10 & 4.31 & - \\
\hline 6.20 & 6.10 & - & - & $3 / 28 / 77$ & .15 & .30 & 10 & 7.49 & 2.00 \\
\hline- & - & 6.39 & - & $10 / 18 / 76$ & - & - & - & 6.659 & 1.10 \\
\hline 4.85 & 4.72 & 5.49 & 3.87 & $5 / 1 / 76$ & - & .15 & 9 & 5.90 & 2.00 \\
\hline 4.95 & 4.50 & 5.62 & 4.38 & $9 / 15 / 76$ & .09 & .18 & 9 & 4.98 & 2.25 \\
\hline- & - & 6.35 & 5.98 & $11 / 1 / 76$ & .15 & .30 & 10 & 6.09 & 1.50 \\
\hline 5.58 & 5.36 & \multicolumn{2}{|c|}{ SALARIED } & $8 / 23 / 76$ & .21 & .21 & 0 & 5.62 & 1.50 \\
\hline 5.80 & 5.45 & 8.06 & 5.38 & $1 / 3 / 77$ & .06 & .12 & 9 & 6.00 & 2.50 \\
\hline 5.12 & 4.80 & SAL & - & $11 / 15 / 76$ & .08 & .16 & 9 & 5.52 & 2.50 \\
\hline$\underline{4.72}$ & $\underline{4.35}$ & - & - & $5 / 14 / 76$ & .20 & .40 & $\underline{9}$ & $\underline{5.46}$ & $\underline{1.75}$ \\
\hline$\overline{5.06}$ & $\overline{4.73}$ & $\overline{5.94}$ & $\overline{4.75}$ & $\overline{12 / 6 / 76}$ & $\overline{.20}$ & $\overline{.20}$ & $\overline{10}$ & $\overline{5.46}$ & $\overline{2.00}$ \\
\hline 5.67 & 4.93 & 8.55 & 4.35 & $7 / 23 / 76$ & .17 & .34 & 10 & 5.73 & - \\
\hline- & 5.78 & \multicolumn{2}{|c|}{ SALARIED } & $10 / 15 / 76$ & $7.5 \%$ & $7.5 \%$ & 10 & 6.318 & 2.00 \\
\hline- & - & 6.35 & 4.44 & $9 / 20 / 76$ & .20 & .40 & 10 & 5.53 & - \\
\hline 5.71 & 5.71 & 8.74 & 3.66 & $8 / 23 / 76$ & .20 & .25 & 10 & 6.71 & - \\
\hline 6.39 & 5.18 & 6.49 & 3.69 & $6 / 1 / 76$ & - & - & 10 & 7.13 & - \\
\hline 5.85 & 4.90 & - & - & $11 / 29 / 76$ & .18 & .26 & 10 & 5.80 & 2.00 \\
\hline 7.39 & 7.34 & 7.52 & 6.85 & $5 / 3 / 76$ & .20 & .40 & 10 & 7.894 & - \\
\hline 6.30 & - & 6.26 & - & $3 / 15 / 77$ & .11 & .22 & 10 & 6.10 & - \\
\hline 6.74 & 6.55 & 6.95 & 6.43 & $1 / 17 / 77$ & .15 & .30 & 10 & 6.58 & 2.50 \\
\hline 5.23 & 5.13 & 6.30 & 4.62 & $11 / 8 / 76$ & .15 & .30 & 10 & 6.24 & 2.00 \\
\hline 5.66 & 5.66 & 8.16 & 5.60 & $6 / 30 / 76$ & .15 & .30 & 10 & 6.70 & 2.00 \\
\hline 4.94 & 4.61 & \multicolumn{2}{|c|}{ SALARIED } & $5 / 23 / 77$ & .15 & .30 & 10 & 5.11 & 2.50 \\
\hline- & - & \multicolumn{2}{|c|}{ SALARIED } & $2 / 9 / 77$ & .10 & .20 & 10 & 5.48 & 2.75 \\
\hline 6.05 & - & \multicolumn{2}{|c|}{ Non-Exempt } & $10 / 1 / 77$ & .14 & .14 & 9 & 6.74 & 1.50 \\
\hline 5.46 & 4.26 & 6.57 & 4.26 & $8 / 9 / 76$ & .10 & .18 & 9 & 5.61 & 2.00 \\
\hline 5.83 & 5.44 & 6.50 & 5.97 & $4 / 4 / 77$ & .10 & .20 & 10 & 6.40 & 2.00 \\
\hline 5.76 & 5.43 & 5.00 & 4.03 & $8 / 27 / 76$ & .10 & .20 & 10 & 5.59 & 1.75 \\
\hline
\end{tabular}

NOTES: 1. All symbols are defined in the paper except SSP and TSP which stand respectively for second shift and third shift premiums.

2. Dashed lines represent information either unavailable or unclear.

3. In firm $N_{0} .19,130$ of 214 hourly employees are unionized and the remaining 84 are not. 